\title{
PERFORMANCE OF FAT-TAILED RAMS FED COMPLETE FEED BASED OIL PALM FRONDS
}

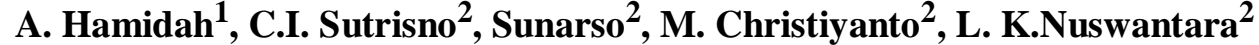 \\ and R.A. Muthalib ${ }^{3}$ \\ ${ }^{1}$ Biology Department, Faculty of Teacher Training and Education, Jambi University, \\ Jl. Raya Jambi-Ma. Jambi Km 15, Mendalo Darat, Jambi - Indonesia \\ ${ }^{2}$ Faculty of Animal Agriculture, Diponegoro University, \\ Tembalang Campus, Semarang 50275 - Indonesia \\ ${ }^{3}$ Faculty of Animal Science, Jambi University, \\ Jl. Raya Jambi-Ma. Jambi Km 15, Mendalo Darat, Jambi - Indonesia \\ Corresponding E-mail: reniamd@yahoo.co.id
}

Received October 14, 2010; Accepted August 22, 2011

\begin{abstract}
The aim of this experiment was to evaluate the performance of fat-tailed rams fed complete feed based oil palm fronds (OPF). This experiment was arranged in Completely Randomized Design (CRD) with 5 treatments and 4 replications i.e. 0, 25, 50, 75 and 100\% of OPF substituting fields grass in complete feed for A, B, C, D and E treatments, respectively. Twenty fat-tailed rams were fed twice at 08.00 and 14.00 with pellet of complete feed for 4 months. The result of this experiment showed that OPF significantly influenced nutrient consumption, average daily gain (ADG) and feed efficiency ratio (FER). Oil palm fronds significantly affected $(\mathrm{P}<0.05)$ fat-tailed rams's dry matter intake $(\mathrm{DMI})$, organic matter intake (OMI), crude protein intake (CPI), ADG and FER. The highest DMI, OMI, CPI, ADG, and FER of fat-tailed rams was in $\mathrm{C}$ treatment and significantly different from the others. It was concluded that $\mathrm{C}$ treatment was the best treatment which can give the best fat-tailed rams performance. The OPF can be used to replace the field grass as feed up to $75 \%$ proportion in complete feed and could increase the performance and productivity of fat-tailed rams.
\end{abstract}

Keywords: Average Daily Gain, Fat-tailed rams, oil palm fronds, performance

\section{INTRODUCTION}

Complete feed is one of the techniques used to improve feed utilization of waste agriculture or plantation and agro-industry through processing with physical treatment and supplementation for ruminant feed production (Wahyono and Hardianto, 2004). The principles of complete feeds formulation were consider the availability of raw materials, cheap, the quality of raw materials. Feedstuff is arranged according to the needs of livestock and divided based on the nutrient content that is dominant as a source of protein, energy, minerals and vitamins. One of the specific potential feed that could be developed in the Province of Jambi is oil palm fronds.

Oil palm fronds (OPF) is a potential feedstuff that can replace the grass. According to BPS of Jambi province (2010), oil palm plantation area in Jambi province reached 493.737 ha, yield 6 tons/month/ha or 72 tons/year/ha. A palm oil plant has 48 pieces of petiole with 250-300 leaves/petiole (Syarif, 2007). Total dry matter OPF produced in a year for each hectare is 5.214 $\mathrm{kg}$ of 20 tons of fresh OPF (Diwyanto et al., 2004). The main problem in using OPF is the low nutrition content. 609 g NDF, 581 g ADF, $28 \mathrm{~g}$ hemicellulose, $481 \mathrm{~g}$ cellulose, and $100 \mathrm{~g}$ acid detergent lignin, $949 \mathrm{~g} / 1000 \mathrm{~g}$ DM (Bengaly et al., 2010). The crude fiber of OPF was $38.5 \%$, NDF 78.7\%, ADF 55.6\%, while crude protein was low only $4.7 \%$ (Alimin and Bejo, 1995). In $1 \mathrm{~kg}$ DM OPF, there is $701 \mathrm{~g} \mathrm{NDF}, 502 \mathrm{~g} \mathrm{ADF}, 198 \mathrm{~g}$ hemicellulose, $424 \mathrm{~g}$ cellulose and $79 \mathrm{~g}$ acid detergent lignin (ADL) (Bengaly et al., 2004). This value can be increased by processing either physically, chemically, biologically or their combinations so it can subtitute the field grass in ruminant ration.

The research of Mathius et al. (2004), Mathius (2008), and Hasan et al. (1992) were more focused on OPF implementation as cow 
ration, and Musnandar et al. (2009) showed that OPF $100 \%$ can be used to replace the grass as Ettawah Crossbred goat ration, while a research to evaluate the effect of use complete feed with the different oil palm frond proportion on fat-tailed rams performance was scarce. The objective of the study was to evaluate the effect of complete feed based oil palm fronds with various proportions on fat-tailed rams performance.

\section{MATERIALS AND METHODS}

The material of this research was twenty male fat-tailed rams with the body weight were $13.85 \pm 0.8 \mathrm{~kg}$ and aged 10-12 months. The research was divided into two phases i.e. preliminary phase and data collection phase. In preliminary phase, preparation of pellet complete feed and male fat-tailed rams as material of research had done. Adaptation on farm environment and feed was done in two weeks, and was continued by observation and data collection in 16 weeks.

The main feedstuffs used to compose the rations were OPF and grass. Oil palm fronds was prepared ammoniation in 4\% urea and 6 days fermentation, with dry matter, ash, crude protein, crude fiber, $\mathrm{ADF}$ and NDF content were 91.42, $7.62, \quad 19.14, \quad 36.55, \quad 54.11$ and $62.73 \%$, respectively (Hamidah et al., 2010). Another feedstuffs used were palm kernel cake, sludge, rice bran, urea, salt, premix, and molasses. All feedstuff was ground and filtered by 60 mesh size filter and then was pelleted in $2 \times 0.5 \mathrm{~cm}$ size to make 5 complete feed formulations (Table 1). Twenty fat-tailed rams in were kept in the pen individually and fed twice daily at 08.00 and 14.00 with pelleted complete feed for 16 weeks. The feed intake was measured by weighing the feed given and the residual. The fat-tailed rams were weighed every 2 weeks. The parameters of this experiment were dry matter intake (DMI), organic matter intake (OMI), crude protein intake (CPI), average daily gain (ADG) and feed efficiency (FER).

1. Dry Matter intake $=($ Feed given residual) $\mathrm{x} \% \mathrm{DM}$ of feed

2. Organic Matter intake $=($ Feed given residual) $\mathrm{x} \% \mathrm{OM}$ of feed

3. ADG $(\mathrm{g} / \mathrm{head} / \mathrm{d})=[$ Final weight $(\mathrm{g})-$ initial weight $(\mathrm{g})] /($ day of measurement]

4. Feed efficiency $(\%)=$ the ADG $(\mathrm{g} / \mathrm{d}) /$ daily dry matter intake $(\mathrm{g} / \mathrm{d})$ x $100 \%$
This experiment was arranged in Completely Randomized Design (CRD) with 5 treatments i.e. $0,25,50,75$ and $100 \%$ of oil palm fronds proportions, respectively for $\mathrm{A}, \mathrm{B}, \mathrm{C}, \mathrm{D}$ and $\mathrm{E}$ treatments and 4 replications. Data were analyzed by analysis of variance, if there was significant effect, was then continued to Duncan Multiple Range Test (DMRT) (Steel and Torrie, 1990).

\section{RESULTS AND DISCUSSION}

Dry matter intake (DMI), organic matter intake (OMI), crude protein intake (CPI), average daily gain (ADG) and feed efficiency rasio (FER) are shown in the Table 2. The result of this experiment showed that OPF proportion and other feed composition in complete feed significantly influenced nutrient intake. Daily DMI of fat-tailed rams in $\mathrm{A}, \mathrm{B}, \mathrm{C}, \mathrm{D}$, and $\mathrm{E}$ treatments were 847.28, $848.39,860.75,856.99$ and $826.78 \mathrm{~g} / \mathrm{head} / \mathrm{day}$, respectively. The treatment significantly $(\mathrm{P}<0.05)$ influenced dry matter intake. According to the Table 2, dry matter intake in $\mathrm{A}, \mathrm{B}, \mathrm{C}$ and $\mathrm{D}$ treatment $(0,25,50$ and $75 \%$ OPF proportion) significantly higher than $100 \%$ OPF proportion (E treatment). The high DMI indicated good feed quality and palatability.

The daily OMI were ranged at 750.20$768.95 \mathrm{~g} / \mathrm{head} /$ day. The lowest OMI was in the $\mathrm{E}$ treatment $(750.38 \mathrm{~g} / \mathrm{head} /$ day $)$, and was not significantly different with $\mathrm{A}$ and $\mathrm{B}$ treatments, but significantly lower with $\mathrm{C}$ and $\mathrm{D}$ treatments. The high feed consumption was correlated with the high animal productivity and was influenced by ruminal capacity, particle size of feed and dry matter's content (Van Soest, 1994). All complete feed have the same particle size of feed. The small particle of feed in pelleted complete feed caused the passage rate of feed in rumen was higher and retention time in rumen was lower than non pellet that caused decreasing feed degradation because only highly digestible portion that could be degraded, while the lowly digestible portion could not be degraded and move out from the rumen. NDF and ADF content also influenced dry matter consumption, energy intake and support normal rumen condition (Mertenz, 2009). The high DMI and OMI indicated many nutrients consumed by fat-tailed rams as energy and protein source that ruminal bacteria need and may increase productivity of fat-tailed rams.

Crude protein intake in this research (in A, $\mathrm{B}, \mathrm{C}, \mathrm{D}$ and $\mathrm{E}$ treatments) were $118.05,123.25$, $124.50,123.58$ and $119.55 \mathrm{~g} / \mathrm{head} / \mathrm{day}$, 
Table 1. The Composition of Feedstuffs to Formulate Complete Feed in Each Treatment

\begin{tabular}{|c|c|c|c|c|c|}
\hline \multirow{2}{*}{ Feed } & \multicolumn{5}{|c|}{ Treatment } \\
\hline & A & B & $\mathrm{C}$ & $\mathrm{D}$ & $\mathrm{E}$ \\
\hline & \multicolumn{5}{|c|}{ 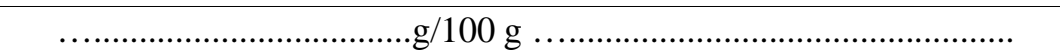 } \\
\hline Field grass & 40.0 & 30.0 & 20.0 & 10.0 & 0.0 \\
\hline Oil Palm Fronds & 0.0 & 10.0 & 20.0 & 30.0 & 40.0 \\
\hline Palm Kernell Cake & 31.5 & 24.5 & 15.8 & 8.0 & 3.5 \\
\hline Sludge & 11.5 & 14.2 & 14 & 13 & 10.5 \\
\hline Rice bran & 12.0 & 16.5 & 25 & 34 & 39.4 \\
\hline Molases & 2.8 & 2.6 & 3.0 & 2.8 & 4.4 \\
\hline Oil palm & 1.0 & 1.0 & 1.0 & 1.0 & 1.0 \\
\hline Urea & 0.2 & 0.2 & 0.2 & 0.2 & 0.2 \\
\hline Salt & 0.5 & 0.5 & 0.5 & 0.5 & 0.5 \\
\hline \multirow[t]{2}{*}{ Premix } & 0.5 & 0.5 & 0.5 & 0.5 & 0.5 \\
\hline & \multicolumn{5}{|c|}{..$\% \ldots \ldots$} \\
\hline $\mathrm{CP}$ & 13.93 & 14.53 & 14.46 & 14.42 & 14.46 \\
\hline $\mathrm{CF}$ & 22.35 & 22.40 & 22.04 & 21.66 & 21.37 \\
\hline $\mathrm{EE}$ & 4.72 & 4.44 & 4.09 & 3.84 & 3.86 \\
\hline Ash & 10.75 & 11.03 & 10.73 & 10.27 & 9.02 \\
\hline NFE & 48.25 & 47.61 & 48.68 & 49.82 & 51.29 \\
\hline $\mathrm{TDN} *$ & 54.99 & 54.68 & 55.22 & 52.86 & 53.93 \\
\hline
\end{tabular}

*TDN values were estimated based on Hartadi et al. (2005)

Table 2. The Feed Intake and Animal Performance in Each Treatment

\begin{tabular}{lccccc}
\hline \multirow{2}{*}{ Variable } & \multicolumn{5}{c}{ OPF Proportion $(\%)$} \\
\cline { 2 - 6 } & 0 & 25 & 50 & 75 & 100 \\
\hline DMI $(\mathrm{g} / \mathrm{d})$ & $847.28^{\mathrm{b}}$ & $848.39^{\mathrm{b}}$ & $860.75^{\mathrm{b}}$ & $856.99^{\mathrm{b}}$ & $826.78^{\mathrm{a}}$ \\
OMI $(\mathrm{g} / \mathrm{d})$ & $756.20^{\mathrm{a}}$ & $754.82^{\mathrm{a}}$ & $768.40^{\mathrm{b}}$ & $768.95^{\mathrm{b}}$ & $750.38^{\mathrm{a}}$ \\
CPI (g/d) & $118.05^{\mathrm{a}}$ & $123.25^{\mathrm{b}}$ & $124.50^{\mathrm{b}}$ & $123.58^{\mathrm{b}}$ & $119.55^{\mathrm{a}}$ \\
ADG (g/head/d) & $86.07^{\mathrm{a}}$ & $110.89^{\mathrm{ab}}$ & $123.77^{\mathrm{b}}$ & $102.05^{\mathrm{a}}$ & $85.63^{\mathrm{a}}$ \\
FER $(\%)$ & $10.16^{\mathrm{a}}$ & $13.08^{\mathrm{b}}$ & $14.38^{\mathrm{b}}$ & $11.92^{\mathrm{a}}$ & $10.36^{\mathrm{a}}$ \\
\hline
\end{tabular}

Value with different superscript at the same row indicates the significantly different $(\mathrm{P}<0.05)$

respectively. Crude protein intake in $\mathrm{B}, \mathrm{C}$, and $\mathrm{D}$ treatment $(25-75 \%$ OPF proportion) were significantly $(\mathrm{P}<0.05)$ higher than $\mathrm{A}$ and $\mathrm{E}$ treatments $(0 \%$ and $100 \%$ OPF proportion). Therefore, the high $\mathrm{CP}$ intake in three OPF proportion $(25,50$ and $75 \%)$ could result in a higher body weight gain than that of 0 and $100 \%$ OPF. Crude protein in the body is required for growth, body development and maintenance of animal.

The average daily gain of fat-tailed rams in each treatments are presented in Table 2. The
ADG of fat-tailed rams were ranged at 85,63 $123.77 \mathrm{~g}$ with average $104.92 \mathrm{~g}$. Oil palm frond proportion significantly influenced $(\mathrm{P}<0.05)$ on ADG of fat-tailed rams. The ADG of fat-tailed rams in $\mathrm{B}$ and $\mathrm{C}$ treatment $(25$ and $50 \%$ OPF proportion) significantly higher than the other treatment. The ADG of fat-tailed rams in this study were lower than the study in indigenous rams fed complete feed by Purbowati et al. (2007) who reported the ADG were 145.22 - $164.98 \mathrm{~g}$. This might be caused by the different kinds and feedstuffs composition compose the complete 
feed.

The main factor affected animal ADG is total nutrients consumed and biological value of feed. Feed consumption showed total energy and nutrient intake to promote the growth and animal production, so that if feed consumption is high, the ADG will also high. Average daily DMI and CPI with CP and TDN content of feed in the researches of Purbowati et al. (2007) and Purbowati et al. (2008) were higher compare to the present study, being $875.86 \mathrm{~g}, 140.87 \mathrm{~g}$, $16.09 \%$, and $54.78 \%$, respectively. However, the present study was higher than the study of Lestari et al. (2003), Wardayanto (2008), Munier et al. (2004), and Akbar (2007) who found that ADG of indigenous rams fed convensional feed were 15.62 - $39.29 \mathrm{~g} ; 55.75,26.47$ and 18.57 $\mathrm{g} /$ head/day, respectively. The lowest ADG in the E treatment $(100 \%$ OPF proportion in complete feed) might be pointed to the high lignin content as well as crude fiber and detergent fiber. The high crude fiber, NDF, ADF and lignin content will decrease the digestibility and failed to increase productivity (Mertenz, 2009).

Feed efficiency in this experiment were ranged at $10.16-14.38 \%$. The highest FER was in the $\mathrm{C}$ treatment and significantly $(\mathrm{P}<0.01)$ different from the others, but it was not significantly different from the B treatment, while the lowest FER was in the E treatment and was not significantly different from the $\mathrm{A}$ and $\mathrm{D}$ treatment. Feed efficiency (FER) in the $\mathrm{C}$ and $\mathrm{B}$ treatment were high. Therefore, its showed that $B$ and $\mathrm{C}$ treatments were the most efficient complete feed than the others. Parakkasi (1999) stated that good feed efficiency value of sheep was $14 \%$ or higher. Based on this statement, the use of $50 \%$ OPF proportion was the most efficient proportion.

\section{CONCLUSION}

Oil palm fronds can be used to replace the field grass in formulation of complete feed for fattailed rams. The oil palm fronds and grass at ratio 50 : 50 was the best ration as proved by best performance and productivity of fat -tailed rams. The giving OPF more than 50\% result in decreasing performance of fat-tailed rams.

\section{REFERENCES}

Akbar, S. A. 2007. Pemanfaatan tandan kosong sawit sawit fermentasi yang dikombinasikan dengan defaunasi dan protein by pass rumen terhadap performans ternak domba. J. Pengembangan Peternakan Tropis. 32(2):8085

Alimin, A.R. and M.H. Bejo.1995. Feeding systems based on oil palm by-products in Malaysia. 1st Int. Symp. on the integration of livestock to oil palm production. MASP/FAO and UPM. $25-27^{\text {th }}$ June 1995. Kuala Lumpur, Malaysia.

Bengaly, K., J.B. Liang, Z.A. Jelan, W. Ho and H.K. Ong. 2004. Optimization of steam treatment as a method to increase in situ degradability of oil palm (Elaeis guineensis) fronds in Malaysia. Livestock Research for Rural Development.16(3):1-6.

Bengaly, K., J. B. Liang, Z. A. Jelan, Y. W. Ho and H. K. Ong. 2010. Ulilization of steamprocessed oil palm (Elaeis guineensis) frond by ruminants in Malaysia: Investigations for nitrogen supplementation. African J. Agric. Res. 5(16):2131-2136

BPS Provinsi Jambi. 2010. Jambi dalam Angka. Badan Pusat Statistik Provinsi Jambi, Jambi.

Diwyanto, K., D. Sitompul, I. Manti, I.W. Mathius and Soentoro. 2004. Pengkajian pengembangan usaha sistem integrasi kelapa sawit-sapi. Prosiding Lokakarya Nasional. Sistem Integrasi Kelapa Sawit- Sapi. Bengkulu, 9-10 September 2003. Badan Penelitian dan Pengembangan Pertanian, bekerjasama dengan Pemerintah Provinsi Bengkulu dan PT. Agricinal. Page. P. 11 - 22.

Hamidah, A., C. I. Sutrisno, Sunarso, and R.A. Muthalib. 2010. Kandungan nutrisi dan kecernaan secara in vitro complete feed berbasis pelepah sawit sebagai pakan domba. Prosiding Seminar Nasional Peternakan Berkelanjutan ke-2. Fakultas Peternakan Universitas Padjajaran. Bandung, 4 Nopember 2010. p. 426-432.

Harris, L.E. 1970. Nutrition Research Technique for Domestic and Wild Animal. Vol.1. Animal Department Utah State University, Logan.

Hartadi, H. S. Reksohadiprodjo and A.D. Tillman. 1997. Tabel Komposisi Pakan untuk Indonesia. Gadjah Mada University Press, Yogyakarta.

Hassan, A.O., M. Ishida, S. Oshio and T.J. Ahmad. 1992. Status of utilization fibrous crop residues and animal performance with emphasis on processing of oil palm fronds (OPF) for ruminant feed in Malaysia. Tropical Agriculture Research Center TARC 
no. 25. Ministry of Agriculture, Forestry and Fisheries, Tsukuba, Japan, Series 24:135-143 Jalaludin, S., Z.A. Zelan, N. Abdullah and Y.W. Ho. 1991. Recent developments in the oil palm byproduct based ruminant feeding system. In : Recent Advances on the Nutrition of Herbivores. Y.W.Ho, H.K. Wong, N. Abdullah and Z.A. Tajuddin (Eds.). MSAP. P 35-44

Lestari, C.M., R. Adiwinarti and Kustiyani. 2003. Penggunaan pakan konvensional untuk penggemukan domba. J. Pengembangan Peternakan Tropis. Special Edition (October 2003):136-141.

Mathius, I.W., Azmi, B. P. Manurung, D. Sitompul, and E. Priyatomo. 2004. Produk samping tanaman dan pengolahan kelapa sawit sebagai bahan pakan ternak sapi potong. Suatu Tinjauan. Prosiding Lokakarya Nasional. Sistem Integrasi Kelapa Sawit-Sapi. Bengkulu, 9-10 September 2003. Badan Penelitian dan Pengembangan Pertanian, bekerjasama dengan Pemerintah Provinsi Bengkulu dan PT. Agricinal. P 120 - 128.

Mathius, I.W. 2008. Pengembangan sapi potong berbasis industri kelapa sawit. Pengembangan Inovasi Pertanian. I(2):206224.

Mertenz, D.R. 2009. Impact of NDF Content and Digestibility on Dairy Cows Performance. WCDS Advances in Dairy Technology. 21:191-201.

Musnandar, E., A. Hamidah, and R. A. Muthalib. 2009. Efek fermentasi terhadap kualitas nutrisi dan kecernaan pelepah sawit. Jurnal Penelitian Universitas Jambi-Seri Sains. 11(2):125-131.

Parakkasi, A. 1999. Ilmu Nutrisi dan Makanan Ternak Ruminan. Cetakan ke-2. Universitas Indonesia Press, Jakarta.

Preston, T.R. and R.A. Leng. 1987. Matching Ruminant Production Systems with Available Resources in The Tropics and SubTropics. Penambul Books, Armidale.

Purbowati, E., C. I. Sutrisno, E. Baliarti, S. P. S. Budhi, and W. Lestariana. 2007. Pemanfaatan protein pakan komplit dengan kandungan protein dan energi yang berbeda pada penggemukan domba lokal jantan secara feedlot. Prosiding Seminar Nasional AINI VI. Yogyakarta, 26-27 Juli 2007:408415.

Purbowati, E., C. I. Sutrisno, E. Baliarti, S. P. S. Budhi, and W. Lestariana. 2008. Pemanfaatan energi pakan komplit berkadar protein-energi berbeda pada domba lokal jantan yang digemukkan secara feedlot. J. Pengembangan Peternakan Tropis. 33 (1):59-65.

Purbowati, E., C. I. Sutrisno, E. Baliarti, S. P .S. Budhi, W. Lestariana, E. Rianto, and Kholidin. 2009. Penampilan produksi domba lokal jantan dengan pakan komplit dari berbagai limbah pertanian dan agroindustri. Prosiding Seminar Nasional Kebangkitan Peternakan. Program Magister Ilmu Ternak, Pascasarjana Fakultas Peternakan, Universitas Diponegoro:130-138.

Steel, R.G. D. and J. H. Torrie. 1990. Principle and Procedure Statistics. $2^{\text {nd }}$ Ed. Mc GrawHill Book Co. Inc., Singapore.

Syarif, S. 2007. Uji palatabilitas beberapa bentuk olahan pelepah sawit terhadap ternak sapi. Jurnal Ilmiah Ilmu-ilmu Peternakan Agustus X (3):156-160.

Tillman, A.D., H. Hartadi, S. Reksohadiprodjo, S. Prawirokusumo, and S. Lebdosukojo. 1998. Ilmu Makanan Ternak Dasar. Gadjah Mada University Press, Yogyakarta.

Van Soest, P.J., J. B. Robertson, and B.A. Lewis. 1994. Methods for dietary fibre, NDF and nonstructural polysaccharides in relation to animal nutrition. J. Dairy Sci.74:3583-3597.

Wahyono, D. E. and R. Hardianto. 2004. Pemanfaatan sumberdaya pakan lokal untuk pengembangan usaha sapi potong. Lokakarya Nasional Sapi Potong. P. 66-76.

Zahari, W. M., O.A. Hassan, H. K. Wong and J. B. Liang. 2003. Utilization oil palm frondbased diet for beef cattle production in Malaysia. Asian-Aust. J. Anim. Sci. 16(4):625-634.

Wardayanto, N. 2008. Penampilan Produksi Domba Lokal Jantan yang Diberi Produk Fermentasi Jerami Padi dengan Ragi Isi Rumen. Tesis. Pascasarjana Magister Ilmu Ternak, Universitas Diponegoro. 